\title{
Do subsidized new firms survive longer? Evidence from a counterfactual approach
}

\section{Guido Pellegrini \& Teo Muccigrosso}

To cite this article: Guido Pellegrini \& Teo Muccigrosso (2016): Do subsidized new firms survive longer? Evidence from a counterfactual approach, Regional Studies, DOI: 10.1080/00343404.2016.1190814

To link to this article: http://dx.doi.org/10.1080/00343404.2016.1190814

View supplementary material $\asymp$

曲 Published online: 12 Jul 2016.

Submit your article to this journal $₫$

Q View related articles $匚$

View Crossmark data $־$ 


\title{
Do subsidized new firms survive longer? Evidence from a counterfactual approach
}

\author{
Guido Pellegrini $^{\mathrm{a}} \odot$ and Teo Muccigrosso ${ }^{\mathrm{b}}$
}

\begin{abstract}
Do subsidized new firms survive longer? Evidence from a counterfactual approach. Regional Studies. This study provides a statistically robust evaluation of the impact of capital subsidies on the survival of start-ups in Italy. The analysis considers the subsidies provided by the main Italian regional policy, Law 488/1992, during 1996-2009. By exploiting an unusual characteristic of the L. 488 selection process, a quasi-experimental design with high internal validity - the regression discontinuity design - is applied for the first time to the survival analysis. The results show a lower default risk in subsidized start-ups. These findings contradict the view that start-ups receiving L. 488 assistance simply used the grant funding to delay exit.
\end{abstract}

KEYWORDS

survival analysis; regression discontinuity design; policy evaluation; public subsidies; regional policy

摘要

受资助的企业是否能生存更久? 来自反事实方法的证据, 区域研究。本研究对资本赞助对于意大利新创企业的生存 之影响，提供统计上可信的评估。本分析考量1996年至2009年间，由主要的意大利区域政策488/1992法案所提供的 资助。本文透过探讨488号法案选择过程的不寻常特徵, 第一次将具有高度内部效度的准实验设计 - 断点迴归设计 应用至生存分析。研究结果显示, 受资助的新创企业拥有较低的违约风险。这些研究发现, 与接受488号法案协助的 新创企业仅只是运用该资金来延迟出场的看法相左。

关键词

生存分析 ; 断点迴归设计 ; 政策评估 ; 公共资助 ; 区域政策

\section{RÉSUMÉ}

Les nouvelles entreprises subventionnées, jouissent-elles d'une plus forte pérennité? Les résultats d'une approche contrefactuelle. Regional Studies. Cette étude fournit une évaluation statistiquement robuste de l'impact des subventions en capital sur la survie des nouvelles entreprises en Italie. L'analyse porte sur les subventions octroyées conformément à la principale politique régionale en vigueur en Italie, à savoir la loi 488/1992, pendant la période allant de 1996 jusqu'à 2009. En exploitant une particularité du processus de sélection de la loi 488, une approche quasiexpérimentale et d'une validité interne élevée - la notion de discontinuité par régression - est appliquée pour la première fois à l'analyse de survie. Les résultats laissent voir des risques de défaillance moins élevées pour ce qui est des nouvelles entreprises subventionnées. Ces résultats vont à l'encontre du point de vue selon lequel les nouvelles entreprises qui bénéficient de l'aide sous l'égide de la loi 488 n'utilisent la subvention que de reporter à plus tard la fermeture.

\section{MOTS-CLÉS}

analyse de survie; discontinuité par régression; évaluation de politique; subventions d'État; politique régionale

\section{CONTACT}

a (Corresponding author) guido.pellegrini@uniroma1.it

Department of Social and Economic Sciences, University of Rome 'La Sapienza', Rome, Italy.

b@muccigrosso@istat.it

Department of National Accounts, Istituto Nazionale di Statistica (ISTAT), Rome. 


\section{ZUSAMMENFASSUNG}

Überleben subventionierte neue Firmen länger? Evidenz eines kontrafaktischen Ansatzes. Regional Studies. Diese Studie enthält eine statistisch robuste Bewertung der Auswirkung von Kapitalsubventionen auf das Überleben von neu gegründeten Firmen in Italien. Bei der Analyse werden die Subventionen untersucht, die aufgrund der wichtigsten italienischen regionalpolitischen Maßnahme, dem Gesetz 488/1992, im Zeitraum von 1996 bis 2009 gewährt wurden. Durch die Nutzung eines ungewöhnlichen Merkmals des Auswahlprozesses von Gesetz 488 wird für die Überlebensanalyse erstmals ein quasi-experimenteller Aufbau mit hoher interner Validität - der RegressionsDiskontinuitäts-Aufbau - angewandt. Die Ergebnisse lassen auf ein niedrigeres Konkursrisiko von subventionierten neu gegründeten Firmen schließen. Diese Resultate widersprechen der Auffassung, dass Neufirmen, die Subventionen nach dem Gesetz 488 erhielten, diese Mittel lediglich zu einer Verzögerung des Konkurses nutzten.

\section{SCHLÜSSELWÖRTER}

Überlebensanalyse; Regressions-Diskontinuitäts-Aufbau; Politikbewertung; staatliche Subventionen; Regionalpolitik

\section{RESUMEN}

¿Sobreviven más las nuevas empresas subvencionadas? Evidencia de un enfoque contrafactual. Regional Studies. Este estudio contiene una sólida evaluación estadística del impacto de las subvenciones de capital en la supervivencia de empresas emergentes en Italia. En el análisis se examinan las subvenciones que se concedieron entre 1996 y 2009 gracias a la principal política regional italiana, Ley 488/1992. Al examinar la particularidad poco usual del proceso de selección de la Ley 488, se aplica por primera vez al análisis de supervivencia un diseño casi experimental con un alto nivel de validez interna: el diseño de regresión descontinuada. Los resultados muestran un riesgo más bajo de impago en las empresas emergentes subvencionadas. Estos resultados contradicen la perspectiva de que las empresas emergentes que recibieron ayuda por la Ley 488 simplemente utilizaban la financiación subvencionada para retrasar el cierre.

\section{PALABRAS CLAVES}

análisis de supervivencia; diseño de regresión descontinuada; evaluación política; subvenciones públicas; política regional

JEL C14, H71, R38

HISTORY Received 14 June 2014; in revised form 2 May 2015

\section{INTRODUCTION}

Public policies enhancing entrepreneurship and the birth of new firms have become increasingly popular: such policies began in the United States in the 1950s and arrived in Europe in the 1980s, having now spread around the world (Greene \& Storey, 2010). The central question is whether all this money is well spent. This is fundamentally an empirical issue. Several studies have assessed the extent of the economic payoffs that public subsidies or government credit guarantees provide to entrepreneurs/start-ups in industrialized countries, but the evaluations have produced contradictory results. This mixed evidence is primarily due to the difficulties of isolating the impact of the policy from the confounding effects induced by other factors. Ideally, a randomized trial, where the subsidized new firms are compared with non-subsidized firms, would allow for the net effect of the policy to be identified. However, high costs, the complexity of the design and ethical issues often prevent the application of this method, and quasi-experimental techniques make it possible to statistically control for heterogeneity and selection bias. Moreover, there are very few studies that explore the impact of public subsidies on the survival of new firms.

This study provides a new and statistically robust evaluation of the impact of capital subsidies on the survival of start-ups in the South of Italy, by exploiting an uncommon characteristic of a regional policy in Italy that creates the conditions for a local random experiment. The analysis considers start-ups subsidized by Law 488/ 1992 (L. 488), which was the primary regional policy instrument in Italy devoted to the creation and support of industrial firms and job creation in less-developed areas through private investment. Thanks to the peculiar L. 488 selection process, the empirical evaluation can assess the effectiveness of these incentives for a relevant subgroup of firms, providing new evidence on the general efficacy of incentives to start-ups. The statistical relevance of the results comes from application, for the first time, of a quasi-experimental design with high internal validity, the regression discontinuity design (RDD), to the survival analysis.

From 1996 (the first operative year) to 2007, L. 488 financed 44,000 projects, granting over $€ 2.3$ billion in subsidies. The total subsidized investments amounted to $€ 87$ billion, 70\% of which were in Southern Italy (Mezzogiorno). Of these projects, $21 \%$ were start-ups.

Among the main objectives of L. 488 is the prevention of sub-optimal investments in the initial stages of ex anteefficient firm projects due to financial constraints. New firms with start-up assistance in form of capital subsidies are expected to invest more, perform better and have higher survival probabilities than they would in the case of constrained entry. Therefore, L. 488 allocates the financial 
resources using a set of indicators that in certain cases clearly favour start-ups.

The main aim of this study is to investigate whether L. 488 positively affected the industry dynamics of the Mezzogiorno regions in terms of the creation and survival probabilities of start-ups. Evaluating the incentives provided to start-ups, as in the evaluation of other policy interventions, faces the problem of isolating the effects of subsidies from the confounding effects induced by other factors. Endogenous participation and high selection bias in the programme require an accurate microeconometric evaluation of their causal effects, but studies in this direction are rare, primarily because of the difficulty of achieving credible identification (Criscuolo, Martin, Overman, \& Van Reenen, 2016). To overcome these problems, the analysis exploits the unique procedure for the allocation of subsidies specified in L. 488. Each year, subsidies are allocated to a broad range of investment projects through regional 'calls for tenders'. In each regional call for tender, the investment projects are ranked on the basis of a score that depends on a number of (known) characteristics of both the project and the firm. Projects receive subsidies according to their position in the ranking until the financial resources granted to each region are exhausted.

The presence of sharp discontinuities in the L. 488 rankings allows one to employ an evaluation method based on a RDD approach, which can identify the causal effect of subsidies on start-up survival. In an RDD approach, the effect of a given policy can be estimated if treatment status is determined by whether an observed forcing variable exceeds a known cut-off point. In the L. 488 case, the critical assumption is that selection into 'treatment' (the subsidy) is exclusively determined by the forcing variable (the score received by the project in the regional ranking). The selection mechanism of L. 488 guarantees that this assumption is compelling, as the allocation of the subsidies is solely based on the forcing variable (the score). Average (local) policy effects are then estimated by comparing the lifetimes of the group of subsidized startups just above the threshold with the lifetimes of the group of start-ups that applied for the incentives but which fell just below the threshold and thus did not receive financing. The study claims that non-financed start-ups (called 'non-treated' firms) with scores just below the threshold are a valid comparison group for those just above the threshold (called 'treated' firms) and described as a valid 'counterfactual scenario': if 'treated' start-ups are similar to 'non-treated' start-ups (around the threshold), no controls or models are needed consistently to detect the effects of subsidies on firm survival.

Recent years have witnessed growing interest in the evaluation of the impact of public subsidies for private firms. However, with respect to the manufacturing sector, the evaluations have produced contradictory results (Cerqua \& Pellegrini, 2014). As far as Italy is concerned, the ex-post impacts of L. 488 in the manufacturing sector have been thoroughly investigated, although, to the authors' knowledge, no empirical study has examined the impact of L. 488 subsidies on the survival probabilities of new-born firms.

Certain studies present evidence that L. 488 positively affects either investment (Adorno, Bernini, \& Pellegrini, 2007; Cerqua \& Pellegrini, 2014) or employment (Bernini \& Pellegrini, 2011; De Castris \& Pellegrini, 2012). L. 488 also generates a time-substitution effect, as financed firms tend significantly to decrease investment activity in the years following programme participation (Bronzini \& De Blasio, 2006).

The main obstacles to firm creation originate in the credit market imperfections. Evans and Jovanovic (1989) show that in case the amount of initial capital that an entrepreneur can borrow is limited, financial constraints make some start-up projects unreachable. Therefore, a start-up subsidy is useful because makes a larger number of projects reachable from the entrepreneur. This imperfection of the credit market also entails a higher failure rate of the new firms, because small firms can only count on their initial capital and on their sales to maintain their activities. Therefore, start-up subsidies should increase the number of firms created and their expected life (Crépon \& Duguet, 2003).

Several studies evaluate the effectiveness of public subsidies or government credit guarantees for entrepreneurs/ start-ups in industrialized countries using ex post impact analyses. Examples include Lerner (1999) for the United States, Fukanuma, Nemoto, and Watanabe (2006) for Japan, Pfeiffer, and Reize (2000) for Germany, Battistin, Gavosto, and Rettore (2001) and Del Monte and Scalera (2001) for Italy, and Crépon and Duguet (2003) and Desiage, Duhautois, and Redor (2015) for France. However, few studies explore the impact of public subsidies on the survival of old and new firms. Rare examples include Battistin et al. (2001), Del Monte and Scalera (2001), Crépon and Duguet (2003) and Prantl (2005). Moreover, the results are ambiguous and contradictory. Battistin et al. (2001) evaluate an Italian programme that promotes youth entrepreneurship by issuing substantial benefits to candidate entrepreneurs selected through a screening process and providing them with training (L. 44/1986). They show that previous results favourable to the programme overstated its effectiveness. The same programme was evaluated by Del Monte and Scalera (2001), who showed that the start-up programme alters the distribution of the firms' life duration, probably because larger subsidies enable stronger shocks to be counteracted. Crépon and Duguet (2003) evaluate the impact of bank loans and start-up subsidies on the survival of new firms. The results show that start-up subsidies significantly increase the survival rates of firms founded by formerly unemployed individuals, while the subsidies have no effect on the survival rates of firms founded by formerly employed individuals. Prantl (2005) examines German federal policies that assist new firms with subsidized medium- or long-term loans. The short-run effect estimates suggest that startup assistance is immediately used to increase start-up investments in assisted firms, but employment remains initially unchanged. 
All these studies analyse the effect of public subsidies on the survival of subsidized new firms using a counterfactual approach, specifically propensity score matching and difference in differences (DID). However, the assumptions behind these techniques are essentially untestable. ${ }^{1}$ The use of sharp RDD for each region in each of the call-fortenders analysed allows one to overcome these identification assumptions: the method is locally equivalent to a random sampling procedure, and the internal validity (around the cut-off) is high (Lee \& Lemieux, 2010), even if the external validity is weak. To the authors' knowledge, no empirical study has investigated the survival probabilities of new-born firms using the RDD approach.

The paper is organized as follows. The next section describes the L. 488 procedures in greater detail. The third section explains the evaluation method proposed. The fourth section presents the new dataset constructed. The results of the empirical analysis and robustness checks are discussed in the fifth section. The paper then briefly concludes and outlines the policy implications of the results.

\section{HOW DOES LAW 488 OPERATE?}

L. 488 allocates project-related capital grants to firms that applied for public support for investment projects in areas designated as Objective 1,2 or $5 b$ for the purpose of European Union Structural Funds, together with some areas that do not qualify for Structural Fund support but which have been approved by the European Commission under Article 92(3)c. ${ }^{2}$ Eligibility for assistance is restricted to manufacturing and extractive firms. ${ }^{3}$ The firms must declare the type of investment project. The investment projects covered by L. 488 are the following: setting-up (investment in new plants), extension (projects that increase the capacity of the firm to produce), modernization (investment in innovation that increases productivity and/or improves working conditions or the environment), restructuring (reorganization and technological renewals), reconversion (adaptation of existing production facilities in order to manufacture different products), reactivation (takeover of unused production facilities) and relocation (eligible only in cases where a transfer of the production facility is required by national or local authorities) (Bronzini \& De Blasio, 2006). Only setting up is related to the construction of new plants, and is the typology used in this study to identify the new-born firms. Therefore, the adopted definition of new-born firm considers only startups (firms born no more than two years before the first call-for-tender for which the firm has applied) with new plants (firms declaring that the subsidies are dedicated to the construction of new plants). ${ }^{4}$

The important feature of L. 488 is the mechanism used to allocate subsidies to the firms. It is a rationing system based on 'calls for tender' that mimics an auction mechanism and which guarantees compatibility of demand and supply of the incentives. There is no entitlement to assistance: applications are ranked on the basis of some predetermined criteria and the subsidies are allocated to projects until funding granted to each region is exhausted. ${ }^{5}$

Incentives are allocated on the basis of regional competitive call-for-tenders. In each call-for-tender, the investment projects are ranked on the basis of five objectives and predetermined criteria: (1) the share of owners' funds of the total investment; (2) the new job creation by unit of investment; (3) the ratio between the subsidy requested by the firm and the highest subsidy applicable; ${ }^{6}$ (4) a score related to the priorities of the region in relation to location, project type and sector; and (5) a score related to the environmental impact of the project. The fourth and fifth criteria were introduced at the third call-for-tender. ${ }^{7}$ The five criteria carry equal weight: the values related to each criterion are normalized, standardized and added up to produce a single score that determines the place of the project in the regional ranking. The normalized score is the forcing variable used in the RDD. The rankings are drawn up in decreasing order of the score awarded to each project and the subsidies are allocated to projects until funding granted to each region is exhausted. The selection procedure is constructed to prevent any interference or subjective evaluation: the ranking and the selection of the group of firms to be subsidized cannot be deliberately manipulated. Several checks are made to determine whether subsidized firms have respected their targets. If a treated firm does not reach its goals, the subsidy is entirely or partially revoked. L. 488 auctions have been issued on a yearly basis.

The analysis refers to first nine L. 488 call-for-tenders in manufacturing that were concluded by 2007. Another essential feature of L. 488 is the timing of the assistance, which is precisely defined and well known by applicant firms. Applications are submitted within a specific deadline (see Table A1 in the supplemental data online). Within four months of the deadline, the Ministry for Industry publishes the rankings. The amounts awarded are paid out in three equal instalments (two if the project is completed within 24 months). L. 488 requires that firms awarded assistance receive the first annual instalment within two months, even if some delays were common in the period. The second and third instalments are paid on the same date in subsequent years and are contingent on two-thirds and the entire investments being realized.

An important issue is the timing of investment and revocation of the subsidy. The eligible investment programmes of L. 488 must be completed within 24 or 48 months from the date of the provisional granting decision, subject to extension authorized by no more than six months. The Ministry of Productive Activities can revoke, in whole or in part, the subsidies in the event that they were diverted from the intended use before five years of their entry into operation.

\section{A METHODOLOGICAL APPROACH FOR SURVIVAL ANALYSIS USING RDD}

The analysis considers nine national calls-for-tenders by regions in the South of Italy. ${ }^{8}$ This framework presents a multiplicity of cut-off points (by call-for-tenders and 
regions) and consequently a multiplicity of treated groups and control groups. To aggregate these observations into a unique sample of treated and non-treated new firms, the scores are standardized by region and call-for-tender. This transformation allows one to identify a unique forcing variable $X$ using the standardized score. Accordingly, the standardized cut-off point is equal to 0 ; the treated firms are those with standardized scores greater than or equal to 0 ; the non-treated firms are those with standardized scores of less than 0 ; and the forcing variable is measured in standard deviation units. For firm $i$ at a specific time $t$, the outcome $Y_{i}$ is represented by a dummy variable that is equal to 0 when the firm experiences a default and equal to 1 if it survives. ${ }^{9}$

A 'sharp' RDD is obtained if only firms that received a grant when their scores are above the threshold are considered 'treated', and only firms with a score below the cut-off point are considered 'non-treated'. The treatment assignment $W$ is a deterministic function of the forcing variable $X$ :

$$
W_{i}=1\left\{X_{i}^{3} c\right\},
$$

where $c$ is the cut-off point. All the firms with standardized scores of at least $c$ are in the treatment group; and all firms with forcing variable values less than $c$ are in the control group. Let $Y_{i}(1)$ and $Y_{i}(0)$ be the potential outcomes for firm $i$, where $Y i(1)$ represents survival at time $t$ and $Y i(0)$ is a default at the same time $t$. The average causal effect of the treatment at the discontinuity point for the sharp RDD (Imbens \& Lemieux, 2008) is:

$$
\tau_{\mathrm{SRD}}=E\left[Y_{i}(1)-Y_{i}(0) \mid X_{i}=c\right]
$$

Under the assumption of the continuity of the conditional regression functions, that is:

$$
E[Y(0) \mid X=x] \text { and } E[Y(1) \mid X=x]
$$

are continuous in $x$, and hence:

$$
\tau_{\mathrm{SRD}}=\lim _{x \downarrow c} E\left[Y_{i} \mid X_{i}=x\right]-\lim _{x \uparrow c} E\left[Y_{i} \mid X_{i}=x\right] .
$$

The estimator consists of the difference between two (parametric or non-parametric) regression functions at that point.

Given the absence of units $X_{i}=c$ for which $Y_{i}(0)$ is observed, the empirical analysis considers units close to the cut-off point. Imbens and Kalyanaraman (2012) suggest how close units must be to the threshold by proposing a data-dependent method for selecting an asymptotically optimal bandwidth for an RDD.

The design is cross-sectional: at time $t$, each firm $i$ is assigned either survival status or default status. If one considers a series of cross-sections over the analysis period, one can verify potentially significant differences in survival probabilities between subsidized and non-subsidized firms. This represents an applicative innovation in the methodology: by being able to observe the difference between the two regression functions at the cut-off point over time, the 'discontinuity' over the experimental period is measured to study the behaviour of treated units with respect to the counterfactual scenario, that is, the non-treated units just below the threshold.

Theoretically, the sharp RDD estimator of the difference between two regression functions at a point over a temporal support is:

$$
\begin{aligned}
t_{\mathrm{SRD}}(t)= & \int_{t=a}^{t=b}\left\{\lim _{x_{t} \downarrow c} E\left[Y(t) \mid X(t)=x_{t}\right]\right. \\
& \left.-\lim _{x_{t} \uparrow c} E\left[Y(t) \mid X(t)=x_{t}\right]\right\} \mathrm{d} t .
\end{aligned}
$$

As the linearity property of the integral is:

$$
\begin{aligned}
\tau_{\mathrm{SRD}}(t)= & \int_{t=a}^{t=b} \lim _{x_{t} \downarrow c} E\left[Y(t) \mid X(t)=x_{t}\right] \mathrm{d} t \\
& -\int_{t=a}^{t=b} \lim _{x_{t} \uparrow c} E\left[Y(t) \mid X(t)=x_{t}\right] \mathrm{d} t .
\end{aligned}
$$

The uniform convergence of difference between the two limits allows one to write:

$$
\begin{aligned}
\tau_{\mathrm{SRD}}(t)= & \lim _{x_{t} \downarrow c} \int_{t=a}^{t=b} E\left[Y(t) \mid X(t)=x_{t}\right] \mathrm{d} t \\
& -\lim _{x_{t} \uparrow c} \int_{t=a}^{t=b} E\left[Y(t) \mid X(t)=x_{t}\right] \mathrm{d} t .
\end{aligned}
$$

Given the time dependency of the data, the estimator consists of the difference between the limits of the integrals of both the regression functions at a given point.

In practice, the best approximation using the above formulation it is a sequence of cross-sections at each day over the period of analysis. This discrete function is a satisfactory solution for approximating the continuous function, and the analysis of annual cross-sections is sufficient to obtain a clear picture of the phenomenon. In this case, the difference in the survival probability between the treated and non-treated firms around the threshold is estimated.

The empirical analysis frequently lacks a deterministic function such as $W$. In this case, an RDD in the 'fuzzy design' configuration can be defined, where the probability of receiving the treatment need not change from 0 to 1 at the cut-off (Imbens \& Lemieux, 2008). There are reasons to consider a fuzzy design in this analytical context that relate to the effect of ex post changes in the rank, exclusions and revocations. These changes could cause a systematic distortion in the estimates. To account for all these causes of rank changing (which were excluded from the sharp design, thereby losing somewhat fewer than the $25 \%$ of the observations), this study also employed a fuzzy design and considers the results of the fuzzy design to be a robustness check of on the results obtained from the sharp design.

Prior studies have evaluated the effect of incentives on the survival of the new firms in a counterfactual framework using the classical methodology for the survival analysis. Originating in the medical and biological research fields, survival analysis has also been widely applied in the social sciences (Hosmer \& Lemeshow, 1999; Therneau \& Grambsch, 2000). The primary tool of survival analysis is 
the Kaplan-Meier estimator (also referred to as the product limit estimator) that estimates the survival probabilities for a sample of units at time $t$.

Let the conditional survival probability over time $t_{(i)}$ be estimated with the ratio $\left(n_{i}-d_{i}\right) / n_{i}$, where $n_{i}$ is the units at risk and $d_{i}$ is the number of failure events (or defaulted units). The Kaplan-Meier estimate, which represents the unconditional survival probability at time $t$, is:

$$
\hat{S}(t)=\prod_{t(i) \leq t} \frac{n_{i}-d_{i}}{n_{i}}
$$

However, the hazard function is defined as the default rate at time $t$ conditional on survival until time $t$ or later:

$$
\begin{aligned}
\lambda(t) & =\lim _{b \rightarrow 0} \frac{P(t \leq T<t+1 \mid T \geq t)}{P(T \geq t)}=\frac{f(t)}{S(t)} \\
& =-\frac{S^{\prime}(t)}{S(t)}=-\frac{\mathrm{d} \log S(t)}{\mathrm{d} t}
\end{aligned}
$$

In a counterfactual approach to survival analysis, the distributions of the functions of the treated and (matched) non-treated groups are compared. The null hypothesis is that the differences between the distribution estimates (i.e., survival function, hazard function, etc.) of two samples are non-significant. The most common tests to verify the significance of this hypothesis are the Wilcoxon and the log-rank tests used in the empirical analysis.

\section{SAMPLES OF SELECTED FIRMS AND THEIR CHARACTERISTICS}

The analysis is based on a new dataset that exploits the administrative data collected by the Italian Ministry of Economic Development, which supervised the implementation of the incentives related to L. 488/1992.

The empirical analysis considers only new firms (located in the Mezzogiorno) with new plants to be safe that are effectively new-born enterprises. If the firm has never been subsidized, the first call-for-tender in which it participated is considered. Moreover, non-subsidized firms above the standardized call-for-tenders threshold (basically, firms with a revoked project) and subsidized firms with standardized scores below the cut-off (for instance, firms not financed by national L. 488 but which received regional subsidies) were excluded, as required by the sharp RDD used. ${ }^{10}$

The main variables available to describe the plants are the following: the region where new plant was built, the sector (NACE Rev. 2) and firm size measured by the number of employees. Among Mezzogiorno regions, Campania has the largest number of new plants, followed by Puglia, Calabria and Sicilia. The remaining 10\% of firms are distributed throughout the other regions of the South of Italy (Abruzzo, Molise, Basilicata and Sardegna) (see Table A2 in the supplemental data online).

Firm size is measured using three size classes based on the number of employees (0-9, 10-249, 250 and more). The size composition reflects the broader structure of Italian manufacturing, as small firms account for approximately $98 \%$ of the sample (see Table A3 in the supplemental data online). Firms with over 250 employees represent $0.6 \%$ of the total number of units.

The proposed investment (in terms of eligible expenditure) is slightly lower in subsidized than in non-subsidized firms (the medians are respectively $€ 735,000$ and $€ 1$ million). Regarding the amount of the subsidy, the variability is higher when one considers the size of subsidy: half the projects receive a subsidy varying between $€ 158,000$ and $€ 750,000$. However, as a share of the investment, the variability is lower: in half the projects the share is between $60 \%$ and $77 \%$.

The composition of the samples remains substantially unchanged if one reduces the bandwidth around the threshold. It can be safely concluded that the treatment and control groups are very similar. However, a counterfactual approach requires using a statistically robust method that addresses selection problems.

\section{EMPIRICAL EVIDENCE}

The study considers firm default as the main event of interest. Five default statuses in the dataset are observed: winding-up, bankruptcy, shutdown, inactivity and cutback. To facilitate interpretation of the results, some of these statuses are reclassified: the first two, reflecting similar conditions, were grouped into a single status that jointly considers winding-up and the declaration of bankruptcy; without affecting the results, the (very few) firms that had suspended activities are dropped. The firms that closed down are divided into two groups: those that closed down definitively and those that closed down due to mergers, conversions or transfers. The last group $(1.3 \%$ of total firms examined) is excluded from the analysis because the event is not considered to be negative (Asquith, Bruner, \& Mullins, 1983). Inactive firms are companies registered with the Registrar of Companies that do not perform the activity. However, they are not cancelled from the archive; therefore, from the authors' point of view, they are alive, even not performing the activity. ${ }^{11}$ As expected, the treatment group contains significantly more active firms during the period of analysis than the control group. However, the shares of firms with inactive and cutback status are higher in the control group (see Table A4 in the supplemental data online). ${ }^{12}$ The considered period is nearly 15 years, from the constitution of the first new plant until April 2009 , when the data were collected.

The outcome is a Bernoulli variable $Y_{i}$ that indicates the survival of a firm $i$ at time $t$. Figure 1 plots the relationship between the forcing variable (standardized score by region and call-for-tender) and the survival rate of the firms by lifetime at three ages (five, eight and 13 years). The survival rate is calculated for intervals (bins) of the forcing variable. Two simple, non-parametric polynomial regressions (for the left and right side of the data with respect to the cutoff point) were used to interpolate the data. The existence of a discontinuity between treated and non-treated firms at the cut-off point is estimated by measuring the jump in the survival rate around the threshold at lifetime $l$, which is 


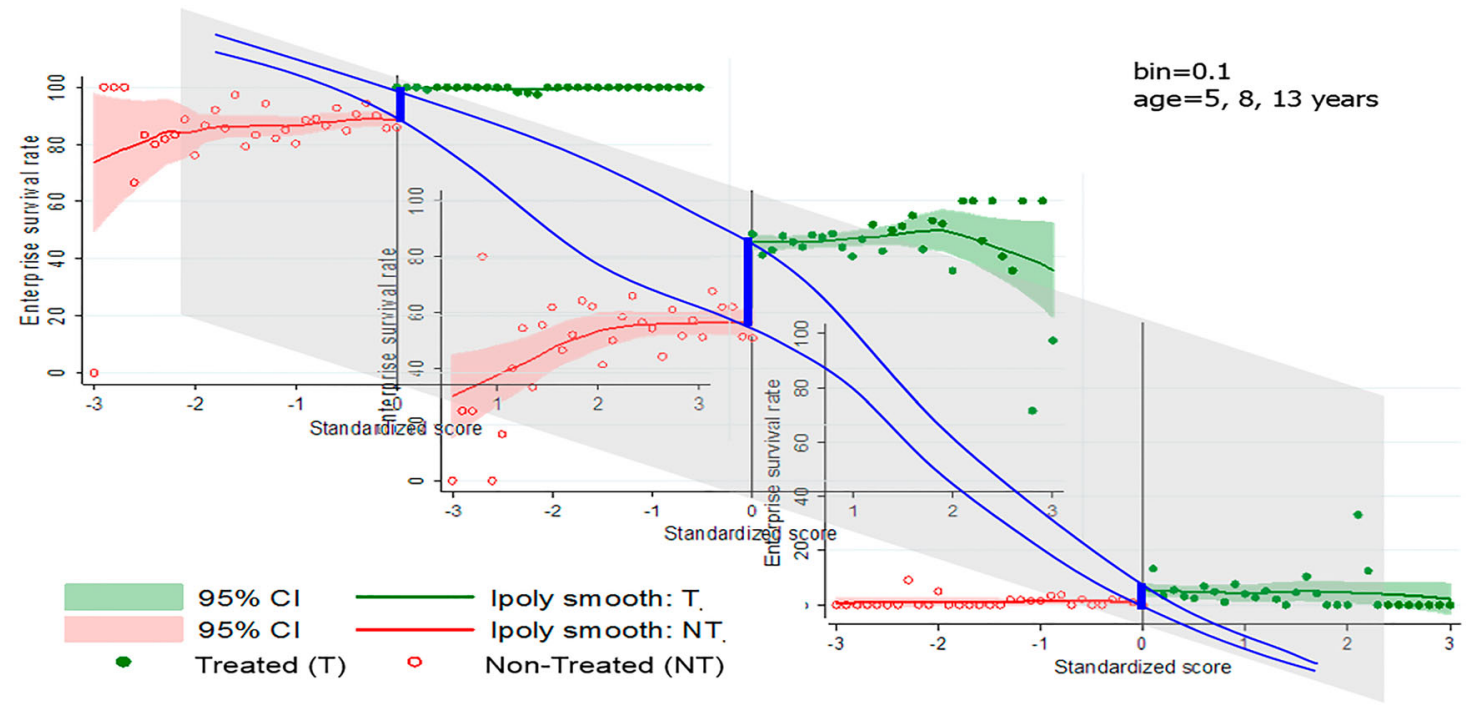

Figure 1. Survival rate: succession of cross-sections applying one-side local linear regressions at the cut-off. Source: Authors' calculations based on Ministry of Economic Development data.

equal to the difference between the right limit and the left

Table 1. Sharp regression discontinuity design (RDD) (nonparametric estimates using optimal and different kernel types): estimation of the differences between treated and non-treated firms.

\begin{tabular}{lcc}
\hline Lifetime & \multicolumn{2}{c}{ Estimation } \\
\cline { 2 - 3 } (years) & $\begin{array}{c}\text { Epanechnikov } \\
\text { kernel }\end{array}$ & $\begin{array}{c}\text { Gaussian } \\
\text { kernel }\end{array}$ \\
\hline 5 & 0.10 & 0.10 \\
6 & $(0.017)^{* * *}$ & $(0.017)^{* * *}$ \\
& 0.25 & 0.25 \\
7 & $(0.03)^{* * *}$ & $(0.029)^{* * *}$ \\
8 & 0.30 & 0.30 \\
& $(0.032)^{* * *}$ & $(0.037)^{* * *}$ \\
9 & 0.27 & 0.26 \\
& $(0.035)^{* * *}$ & $(0.033)^{* * *}$ \\
10 & 0.17 & 0.16 \\
& $(0.037)^{* * *}$ & $(0.044)^{* * *}$ \\
11 & 0.10 & 0.09 \\
& $(0.042)^{* *}$ & $(0.039)^{* *}$ \\
12 & 0.111 & 0.106 \\
13 & $(0.041)^{* * *}$ & $(0.04)^{* * *}$ \\
& 0.07 & 0.07 \\
& $(0.036)^{*}$ & $(0.033)^{* *}$ \\
& 0.05 & 0.05 \\
& $(0.015)^{* * *}$ & $(0.014)^{* * *}$ \\
\hline
\end{tabular}

Notes: The sample consisted of 1910 treated and 2435 non-treated firms. One-side local linear regressions at cut-off are estimated. Optimal bandwidth $=50$ replications.

Bootstrapped standard errors are given in parentheses. * Significant at the $10 \%$ level; **significant at the $5 \%$ level; *** significant at the $1 \%$ level. Source: Authors' calculations based on Ministry of Economic Development data. limit of the two polynomial regressions at the cut-off point. This reflects the effects of the policy effect on the survival rate when the firms reach $l$ years of age. This preliminary approach provides initial evidence of a higher survival rate among the treated firms than their non-treated counterparts throughout the period considered. By testing a succession of cross-sections along the time axis, the significance of the policy is evaluated. These non-parametric estimations were conducted for every year after the firms' fifth year. ${ }^{13}$

RDD was estimated using different kernel functions (Epanechnikov, Gaussian) and bandwidths larger and smaller than the optimal bandwidth to check the robustness of the results. Standard errors were estimated using a bootstrap procedure. The results are clear and highly significant. The difference between the survival probabilities of the subsidized and the non-subsidized firms in each year is positive and statistically significant (Table 1).

Treated firms have a $10 \%$ higher survival probability at five years of age; the difference in survival probabilities is maximized for firms between seven and eight years of age (25-30\%); this difference declines after seven years, with an inflexion point only being observed between the ages of 10 and 11 years. The confidence interval does not cross the axis at the zero point in any year of analysis (Figure 2).

The differences in survival probabilities between treated and non-treated firms by years are rather coherent with the expectations. Differences are lower, even if statistically significant, in the first years after the start of the investment project. The interpretation here is that treated and nontreated new-born firms around the cut-offs are quite similar. The difference in the survival rates, given by the treatment, tends to growth in time (from the fifth year to the seventh year). After that, the effect of the subsidy starts to be less important and the gap starts reducing. However, 


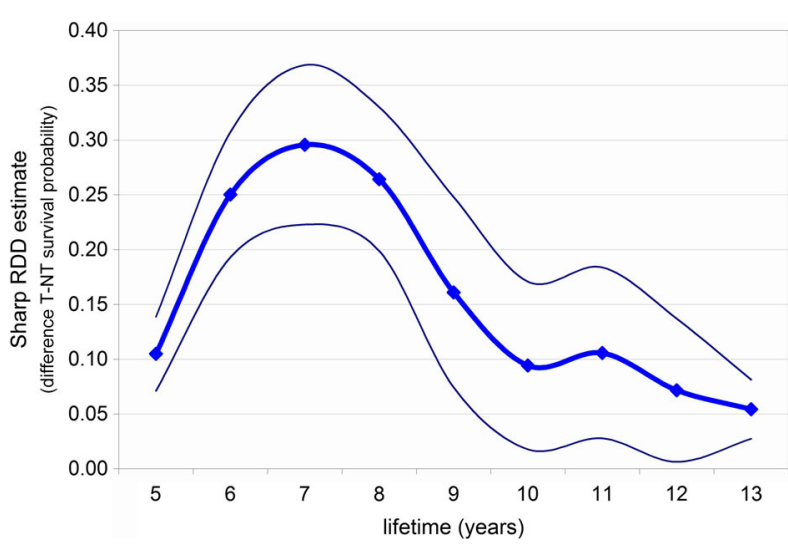

Figure 2. Sharp regression discontinuity design (RDD) estimate: difference in survival probabilities between treated and non-treated firms.

Note: Thin lines bound the 95\% confidence interval. One-side local linear regressions at estimated at the cut-off. Optimal bandwidth, 50 replications.

Source: Authors' calculations based on Ministry of Economic Development data.

after 13 years, the gap is still positive and statistically significant. The principal explanation of the reduction of the difference in survival probability between subsidized and non-subsidized firms after the seventh year is that subsidized firms could prefer starting to dismiss the subsidized capital seven to nine years or more after the grant to avoid having to return the money. Another explanation (which does not replace the previous one) is that if subsidies were used to buy a more up-to-date capital, after seven years the new capital would have been obsolete. However, the gap in survival probability after the ninth year remains similar to the value of the gap in the fifth year (around $10 \%)$. The difference in survival probability is always positive and statistically significant, from the fifth to the 13th year after the grant. This could be a signal that the subsidy was helpful (on average) to the subsidized firms, for instance increasing productivity and competitiveness through the acquisition of a better and more innovative capital.

\section{Robustness proofs}

As Imbens and Lemieux (2008) suggest, the robustness of the results can be assessed by testing several aspects of the data. Some evidence about two key tests is shown. First, the histogram of the distribution of standardized scores is drawn to verify discontinuities in the conditional density on the forcing variable, which could indicate ex ante manipulation of the ranking by firms (see Figure A1 in the supplemental data online). There is no evidence of discontinuities in the distribution around the cut-off point, also using different bin sizes.

A more formal test of manipulation related to the continuity in the density of the forcing variable is by McCrary (2008). The weak discontinuity around the cut-off point is not statistically significant (the discontinuity estimate is 0.036 , the standard error is 0.076 ).
As an additional robustness check, the sharp RDD is also estimated by using the deviations from the mean of the respective call-for-tender and region combinations to determine whether the variability in the scores by callfor-tender and region are relevant. The results do not differ significantly from the estimates made with standardized scores. The paper also tested whether the results are unaffected by the presence of heterogeneity in firms' characteristics around the threshold.

An important question is the role of inactive firms. The authors are aware that the active/inactive status in the Infocamere Archive may be poorly measured. Therefore, the probability of default dropping the inactive firms in the treated and non-treated samples was re-estimated. The main results are basically the same: the survival probability of treated firms is always higher than non-treated firms.

\section{Fuzzy design results}

The sharp design requires that non-subsidized firms above the standardized call-for-tenders threshold (for instance, revoked firms) and subsidized firms with standardized scores below the cut-off (for instance, firms that received regional subsidies) be excluded and therefore leads to a loss of information. A viable alternative is to conduct RDD estimates using the fuzzy approach. However, 'fuzziness' is strictly related to each idiosyncratic combination of a region and a call-for-tender. Subsidized firms are among the non-subsidized ones because every call-for-tender is managed at the regional level, and each region can choose to subsidize several firms that did not receive national subsidies because they were under the cut-off point in the regional ranking. ${ }^{14}$ The authors, therefore, can only estimate fuzzy designs for each region/call-for-tender pair. The fuzzy estimate is only feasible for a few combinations of region and call-for-tenders. An appreciable number of firms belong to the Calabria and Campania regions for several call-for-tenders (numbers three, four and eight), although the degrees of freedom are substantially lower than in the sharp design. The RDD estimates for these couples are ambiguous. The estimates for Calabria are not statistically significant (likely due to the small number of observations). In Campania, the estimates are positive and statistically significant for the call-for-tenders numbers three and four but not for numbers eight (see Table A4 in the supplemental data online).

The indeterminacy of the results obtained in the fuzzy analysis is also the result of the nature of the fuzziness approach. The treatment assignment variable $W_{i}$ in the fuzzy design should be a random variable given $X_{i}$. This is the crucial point: the differences from the sharp assignment observed in the fuzzy design should be random. This is not the case in the present data because assignment depends on regional decisions. The authors have carefully checked that the discontinuity threshold has been properly identified: the analysis confirmed that in the first publication of the call-for-tender list, the incentives are awarded only to winning firms, while in the later stages some winning firms' subsidies are revoked (non-treated winners) and other non-winners are supported (treated non-winners). 
Therefore, particular attention should be paid to the output of the fuzzy design. These results can suffer from a systematic distortion due to the data-generating process, which differs from that of the sharp design.

\section{CLASSICAL SURVIVAL ANALYSIS}

The classical survival analysis approach provides an additional robustness check. Overall, the results produced by the Kaplan-Meier estimator are comparable with the RDD estimates. Exact statistical matching (based on size, sector and region) is used to reduce the selection bias. The differences in survival probabilities are lower when an ex post sample selection is applied to the control group. The subsidized firms exhibit a $10 \%$ greater probability of surviving for five years than the non-subsidized firms, and this difference increases to $20 \%$ at 10 years and to $30 \%$ at 14 years (see Figure A2 in the supplemental data online). Both the log-rank and Wilcoxon tests reject the hypothesis that the two groups of firms share a common survival function.

\section{CONCLUSIONS}

This study sheds a new light on the impact of L. 488 subsidies on the survival probabilities of new-born firms. The empirical evidence is statistically robust: the new, subsidized firms in the Mezzogiorno survive longer than their non-subsidized counterparts, ceteris paribus. The results can be summarized as follows:

- At a given age, the subsidized firms consistently exhibit a statistically significantly higher survival rate than the non-subsidized firms.

- At each age, treated firms exhibit a default probability in the following year that is constantly lower that the nontreated firms.

- During the 15 years considered, the survival probability of the new, subsidized firms after five years is nearly equal to 1 (as a consequence of the regulations in L. 488); after seven years, the difference in survival probability with respect to non-subsidized firms is the highest in the period observed (approximately 30\%). This difference declines thereafter (with the exception of an inflexion point around the 10th year). The dynamics can be consistent with the hypothesis of delayed death to avoid revoking of subsidies. However, after the ninth year the difference is around $10 \%$ in the following two years, before declining to $5 \%$ in the next two years. On average, the difference is equal to $21 \%$ in the year from the fifth to the ninth from the starting of the investment, $8 \%$ from the 10 th to the 13 th year.

These findings contradict the view that entrepreneurs receiving L. 488 start-up assistance simply used the grant funding to delay exit, because the difference in the survival probability remains statistically significant even after the end of the required period for subsidy revocation. The analysis suggests that one of the targets of L. 488 (increasing the survival probabilities of new-born firms) has been achieved. The results are in line with those of Crépon and Duguet (2003) for France and of Prantl (2005) for Germany. However, the conclusions differ from those of by Battistin et al. (2001), who found evidence that a few months after birth the subsidized new firms begin dying at an increasing rate as the amount of subsidies decreases, a pattern that is peculiar to subsidized firms. Their interpretation of this evidence is that subsidized firms' survival probabilities depend on subsidies. In the results the default probability of a subsidized new firm is always higher that of a non-treated counterpart.

An interesting issue concerns the cost of the intervention compared with its benefits. Dividing the average amount of the subsidies by the average additional employment per year, it is found that each additional new job has cost around $€ 29,585$ per year. The estimates are larger than those retrieved by Criscuolo et al. (2016) and Cerqua and Pellegrini (2014). These figures are consistent with the nature of the investments subsidized by L. 488 in the sample: the start-ups need new capital, and therefore the amount of investment and investment for employee is higher than average.

However, even if the evaluation procedure is robust with respect to several features of L. 488, the generalization of the findings to firms far to the threshold should be done with caution. External validity of the results is, in fact, limited by the methodological approach used.

Finally, an important question posed by Battistin et al. (2001, p. 181) is related to the selectivity of the programme:

what matters for the success of such programmes is not how effective the subsidy per se is in keeping firms alive but how well selected the beneficiaries are. To prevent this dependence of firms on subsidies only 'good' firms should be selected ....

This is also true in this case: the selection mechanism of L. 488 can choose the new firms that are most likely to survive. Nevertheless, the use of the RDD to exploit the unique procedure for subsidy allocation stipulated in L. 488 allows one to control thoroughly for selection bias, giving robust results with strong internal validity.

\section{ACKNOWLEDGEMENTS}

The authors are grateful to participants at seminars in Rome (Sapienza University and Tor Vergata University) and Turin (AISRE), and to Augusto Cerqua, Marusca De Castris and the anonymous referees for the useful comments and suggestions. They thank Salvatore Mignano, Ministry of Economic Development, who made the administrative dataset of Law 488/1996 available. The views expressed in this article are those of the authors and do not necessarily reflect those of the Istituto Nazionale di Statistica (ISTAT). 


\section{DISCLOSURE STATEMENT}

No potential conflict of interest was reported by the authors.

\section{FUNDING}

This work was supported by the Sapienza University of Rome Postdoctoral Fellowship 'Statistical Methods for the Evaluation of Public Policies'.

\section{SUPPLEMENTAL DATA}

Supplemental data for this article can be accessed at http://dx.doi.org10.1080/00343404.2016.1190814

\section{NOTES}

1. See, inter alia, Blundell and Costa Dias (2009) for descriptions of the difference-in-difference, matching and difference-in-differences matching estimators.

2. Objective 1 corresponds to all regions in the South of Italy, except for Abruzzi, which lost its Objective 1 status at the end of 1996; while the Objective 2 and $5 \mathrm{~b}$ areas are all located in the Centre-North of the country or Abruzzi. For more details on the features of L. 488, see Bronzini and De Blasio (2006).

3. Since 2001, the L. 488 scheme has been extended with separate auctions to the tourism, trade and transport sectors. This paper only considers subsidies to manufacturing sectors.

4. However, in the sample, $82.7 \%$ of the firms were founded not more than one year before the call for tender. See the fourth section for more details.

5. Firms that apply for the incentives renounce any other public subsidies, even without any guarantee of receiving the L. 488 funds.

6. The lower this ratio, the more likely is the firm to obtain the subsidy. The highest subsidy applicable is determined by the European Union and varies with the dimension of the firm (favouring small firms) and with the location of the production unit (favouring the most disadvantaged areas).

7. These new indicators, signalling only the absence/ presence of certain requirements, have played a minor role in determining the rankings. Therefore, the heterogeneity in the number of indicators should not affect the quality of the ranking, and scores calculated with a different number of indicators can safely be pooled together. For a detailed description of the rationale of each indicator, see Bernini and Pellegrini (2011), section 3.

8. The intensity of the subsidy is far higher in the southern regions: they are the only eight Objective 1 Italian regions in the 1994-99 European Union regional policy cycle.

9. This is a standard approach in the presence of multiple cut-off but similar samples. The design is converted into a two-dimensional RD: for each cut-off, the assignment variable is centred at 0 and all observations are pooled into a single dataset (e.g., Jackson et al., 2007). However, this procedure relies on the assumption of the random allocation of subsidies to the firms ranked around the unique cut-off point.

10. Moreover, firms interested in merger, acquisition, conversions or transfers in the period (less than the $2 \%$ of the total) were dropped. For the fuzzy RDD, see the fifth section.

11. There are several problems related to the active/ inactive status in the Infocamere Archive. The Infocamere Glossary states that in some cases there is a considerable presence of companies that are inactive for the registry, but they actually are not, especially those registered in the Rome Archive'. Therefore, it was decided to apply the more conservative hypothesis, i.e., that inactive firms are alive. Actually, the adoption of such an assumption strengthens the results: the survival probability of treated firms is higher than the plausibly overestimated survival probability of non-treated firms, and the difference is statistically significant.

12. One reason is that many of the registered firms never started the activity because they never received the grant. This explains why there are more inactive firms in the control group with respect to the treatment group.

13. The incentives of Law 488 are only confirmed if the new plants reach at least five years of age.

14. On the contrary, the decision to revoke the Law 488 subsidy depends only on the failure to respect some parameters, and therefore it is independent from regional authorities.

\section{ORCiD}

Guido Pellegrini @ http://orcid.org/0000-0002-6325-7351

\section{REFERENCES}

Adorno, V., Bernini, C., \& Pellegrini, G. (2007). The impact of capital subsidies: New estimation under continuous treatment. Giornale degli economisti e annali di economia, 66(1), 67-92.

Asquith, P., Bruner, R., \& Mullins, D. (1983). The gains to bidding firms from merger. Journal of Financial Economics, 11, 121-39. doi:10.1016/0304-405X(83)90007-7

Battistin, E., Gavosto, A., \& Rettore, E. (2001). Why do subsidized firms survive longer? An evaluation of a program promoting youth entrepreneurship in Italy. In M. Lechner \& F. Pfeiffer (Eds.), Econometric evaluation of active labour market policies in Europe (pp. 153-181). Heidelberg: Physica.

Bernini, C., \& Pellegrini, G. (2011). How are growth and productivity in private firms affected by public subsidy? Evidence from a regional policy. Regional Science and Urban Economics, 41(3), 253-265. doi:10.1016/j.regsciurbeco.2011.01.005

Blundell, R., \& Costa Dias, M. (2009). Alternative approaches to evaluation in empirical microeconomics. Journal of Human Resources, 44, 565-640.

Bronzini, R., \& De Blasio, G. (2006). Evaluating the impact of investment incentives: The case of Italy's Law 488/1992. Journal of Urban Economics, 60(2), 327-349. doi:10.1016/j.jue. 2006.03.005

Cerqua, A., \& Pellegrini, G. (2014). Do Subsidies to private capital boost firms' growth? A multiple regression discontinuity design 
approach. Journal of Public Economics, 109, 114-126. doi:10. 1016/j.jpubeco.2013.11.005

Crépon, B., \& Duguet, E. (2003). Bank loans, start-up subsidies and the survival of the new firms: An econometric analysis at the entrepreneur level. Cabiers de la MSE - EUREQua, 2003(77).

Criscuolo, C., Martin, R., Overman, H., \& Van Reenen, J. (2016). The causal effects of an industrial policy (CEP Discussion Paper No. 1113). London: Centre for Economic Performance (CEP).

De Castris, M., \& Pellegrini, G. (2012). Evaluation of spatial effects of capital subsidies in the South of Italy. Regional Studies, 46(4), 525-538. doi:10.1080/00343404.2010.509130

Del Monte, A., \& Scalera, D. (2001). The life duration of small firms born within a start-up programme: Evidence from Italy. Regional Studies, 35(1), 11-21. doi:10.1080/00343400120025646

Desiage, L., Duhautois, R., \& Redor, D. (2015). Long term effect of public subsidies on start-up survival and economic performance: An empirical study with French data. Revue d'économie industrielle, $O(1), 11-41$.

Evans, D., \& Jovanovic, B. (1989). An estimated model of entrepreneurial choice under liquidity constraints. Journal of Political Economy, 97(4), 808-827. doi:10.1086/261629

Fukanuma, H., Nemoto, T., \& Watanabe, W. (2006). Do governmental financial institutions belp startups grow? Evidence from Japan. Paper presented at the 'Public versus Private Ownership of Financial Institutions' conference, Center for Financial Studies, Universitat Frankfurt. Mimeo.

Greene, F. J., \& Storey, D. J. (2010). Entrepreneurship and small business policy: Evaluating its role and purpose. In D. Coen, W. Grant, \& G. Wilson (Eds.), The Oxford handbook of business and government (pp. 601-621). Oxford: Oxford University Press.
Hosmer, D. Jr. \& Lemeshow, S. (1999). Applied survival analysis. New York: Wiley.

Imbens, G., \& Lemieux, T. (2008). Regression discontinuity designs: A guide to practice. Journal of Econometrics, 142(2), 615-635. doi:10.1016/j.jeconom.2007.05.001

Imbens, G. W., \& Kalyanaraman, K. (2012). Optimal bandwidth choice for the regression discontinuity estimator. Review of Economic Studies, 79(3), 933-959. doi:10.1093/restud/rdr043

Jackson, R., McCoy, A., Pistorino, C., Wilkinson, A., Burghardt, J., Clark, M., ... Swank, P. (2007). National evaluation of early reading first: Final Report. Washington, DC: US Department of Education, Institute of Education Sciences/US Government Printing Office.

Lee, D. S., \& Lemieux, T. (2010). Regression discontinuity designs in economics. Journal of Economic Literature, 48(2), 281-355. doi:10.1257/jel.48.2.281

Lerner, J. (1999). The government as venture capitalist: The long-run impact of the SBIR program. Journal of Business, 72, 285-318. doi:10.1086/209616

McCrary, J. (2008). Manipulation of the running variable in the regression discontinuity design: A density test. Journal of Econometrics, 142, 698-714. doi:10.1016/j.jeconom.2007.05.005

Pfeiffer, F., \& Reize, F. (2000). Business start-ups by the unemployed - An econometric analysis based on firm data. Labour Economics, 7(5), 629-663. doi:10.1016/S0927-5371(00)00016-6

Prantl, S. (2005). The role of policies supporting new firms: An evaluation for Germany after reunification (Mimeo). Berlin: Wissenschaftszentrum Berlin für Sozialforschung (WZB).

Therneau, T., \& Grambsch, P. (2000). Modelling survival data. Berlin: Springer. 